\title{
Pengembangan Modul Bimbingan Karier Berbasis Pendekatan Karakter Kinerja di SMA
}

\author{
Samy Purnamy Drachman, Rufi'i, Muhammad Muhyi \\ Program Studi Teknologi Pendidikan, Program Pascasarjana, \\ Universitas PGRI Adi Buana Surabaya, Indonesia
}

\section{Edcomtech}

\author{
Jurnal Kajian \\ Teknologi Pendidikan \\ Volume 5, No 1, April 2020 \\ 180-191
}

Submitted 24-02-2020

Accepted 03-03-2020

Corresponding Author

Samy Purnamy Drachman

samypurnamydrachman@gmail.com

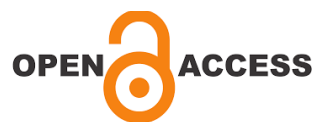

\begin{abstract}
Abstrak
Program pengembangan karier merupakan jembatan bagi siswa untuk menggapai lapangan kerja yang diimpikan. Penelitian ini menggunakan metode penelitian pengembangan dengan berkontribusi pada ketiadaan modul bimbingan karier yang menjadi fondasi pengambilan keputusan jenjang karier siswa dengan fokus di pengembangan karakter. 60 siswa berpartisipasi dalam penelitian pengembangan modul ini dan diolah secara deskriptif kuantitatif. Hasil penelitian ini mendapati bahwa validasi desain adalah 92\% dengan nilai rerata 4,6 dalam kategori 'baik'. Validasi konten adalah 96\% dengan nilai rerata 4,8 (baik). Validasi instrumen baik. Validasi rekan diperoleh 92\% dengan nilai rerata 4,6 (baik). Kemudian dilanjutkan ke tahap pengembangan. Hasil uji coba kelompok kecil adalah 88,5\%. Hasil uji coba kelompok sedang adalah 91,8\%. Hasil uji coba kelompok besar adalah 93,1\%. Berdasarkan pendekatan karakter kinerja, modul ini dinyatakan layak untuk digunakan. Studi ini menawarkan informasi berharga kepada konselor sekolah, pengawas konseling, dan pendidik konselor.
\end{abstract}

Kata Kunci: Modul, Bimbingan Karier, Karakter, Kinerja

\begin{abstract}
The career development program aimed to guide students to secure employment. This study contributed to the discussion by developing a career development module with character development as guidance of students' decision making. Sixty students participated in this study, analyzed with a quantitative descriptive method. This study revealed that the design validation was 92\%, with 4,6, as good. Content validation was $96 \%$ or the average of 4,8 (good). Instrument Validation was also good. Partner validation was 92\%, or 4,6 (good). After designing, this study applied the development test. The result revealed the test of small group to be $88,5 \%$, middle group to be $91,8 \%$, and big group to be $93,1 \%$. This study concluded the career development module was good for field application, and offered precious information to the school counselor, counseling supervisor, and the counselor herself.
\end{abstract}

Keywords: Module, Career Development, Character, Performance 


\section{PENDAHULUAN}

Dibandingkan siswa sekolah vokasi, sekolah umum seperti SMA tidak memiliki pengetahuan khusus mengenai pekerjaan sebagaimana anak SMK. Karenanya murid sekolah vokasi cenderung lebih cepat untuk diterima bekerja (Forster, Bol, \& van de Werfhorst, 2016). Kurikulum pendidikan vokasi juga diarahkan pada beragam upaya untuk mendapatkan pekerjaan secara cepat (D. K. Riyadi, Dian, Degeng, \& Junining, 2019). Permasalahan bagi siswa vokasi adalah kemampuan untuk adaptasi yang rendah pada saat mereka telah mencapai usia lanjut, sehingga rentan untuk digantikan dengan beragam teknologi (Hanushek, Schwerdt, Woessmann, \& Zhang, 2017).

Bagi siswa SMA yang memiliki pengetahuan bersifat umum, maka diperlukan pendampingan yang tepat, maju dan komprehensif (Abel, Deitz, \& Su, 2014). Hal ini menyebabkan perlunya pendampingan yang dilakukan oleh orang yang memiliki ilmu pengetahuan yang memadai di bidangnya. Salah satunya adalah Guru Bimbingan Konseling (BK) yang profesinya disebut sebagai Konselor (Morgan, Greenwaldt, \& Gosselin, 2014). Peran konselor amat penting, di tengah perkembangan zaman dengan sistem teknologi informasi yang semakin pesat (Falco, 2017).

Pendampingan yang tidak maksimal dalam membantu siswa menentukan alur pendidikan untuk mencapai karier yang diinginkan membuat siswa merasa bingung di akhir masa sekolah, meskipun di awal sekolah pernah diadakan tes bakat dan minat. Ketika tidak ada tindak lanjut yang maksimal dari Konselor, baik kegigihan, kedisiplinan, ketelitian dan kecermatan (karakter kinerja) maka siswa tetap kebingungan, terutama di jenjang kelas 3 Sekolah Menengah Atas (SMA). Selain itu, seorang siswa memerlukan pendampingan ketika berkeinginan mendaftar di suatu perguruan tinggi agar mampu menentukan pilihan yang tepat (Bain, 2012).

Beberapa penelitian telah dilakukan untuk mengembangkan modul bimbingan karier siswa. Di antaranya adalah pemetaan berdasarkan keahlian siswa dengan metode simple additive weighting (Septani, Elmunsya,
\& Pujianto, 2019). Peneliti yang lain mengembangkan modul bimbingan karier multimedia interaktif untuk meningkatkan kematangan karier siswa (Leksana, 2015), untuk meningkatkan jiwa wirausaha remaja (Na'imah \& Rahardjo, 2012), etc. Penelitianpenelitian ini menunjukkan adanya upaya untuk meningkatkan layangan bimbingan di tingkat sekolah menengah atas.

Fenomena penelitian di atas menciptakan sebuah ruang untuk penelitian lanjutan, dimana peran bimbingan konseling untuk mempersiapkan siswa SMA untuk mendapatkan pekerjaan masih kurang menjadi bahasan dalam kajian, terkhusus pada pengembangan modul khusus berdasarkan pengalaman di Indonesia. Apatah lagi, modul pengembangan karier berbasis pengembangan karakter belum banyak menjadi kajian penelitian.

Berdasarkan uraian di atas, artikel ini berupaya memberikan sumbangsih pengetahuan dan aplikasi dengan mengembangkan perangkat bimbingan untuk dapat membantu menentukan pilihan karier siswa berupa modul. Modul ini diarahkan pada materi umum tentang perkembangan masa depan, sikap dan minat terhadap apa yang diminati tentang pilihan, serta dampak salah pilih dalam menentukan karier yang dipengaruhi faktor intrinsik dan ekstrinsik siswa yang mengarah pada karakter kinerja.

\section{METODE}

Penelitian yang dilakukan oleh Peneliti merupakan jenis penelitian pengembangan (development research) yang fokus pada pengembangan suatu produk yang nantinya dapat digunakan untuk membantu dalam penentuan keputusan dalam pengambilan keputusan yang terbaik atas permasalahan penelitian yang diangkat. Pengembangan adalah jenis penelitian yang merupakan cara sistematis yang digunakan untuk membuat rancangan, mengembangkan program dan produk yang memenuhi kriteria secara ilmiah (Sugiyono, 2016). Atas dasar definisi tersebut maka jenis penelitian pengembangan diarahkan pada pengembangan produk berupa modul bimbingan karier yang berbasis pendekatan karakter kinerja fokus pada nilai 
disiplin siswa untuk tingkat Sekolah Menengah Atas (SMA) (Sugiyono, 2016).

Terdapat sepuluh langkah rancangan penelitian pengembangan (Gall, M. D., Gall, J. P., \& Borg, 2003). Tahapan tersebut meliputi: analisis kebutuhan, perancangan produk, validasi, uji coba produk untuk kelompok kecil, sedang, dan besar, serta diseminasi produk.

Penelitian dilakukan di lingkungan SMA Negeri 16 pada siswa kelas XII yang berlokasi di kota Surabaya. Seluruh subjek penelitian yang ada adalah siswa SMA Negeri Kelas $X$, XI dan XII yang kemudian disebut sebagai populasi dalam penelitian pengembangan ini, sedangkan yang menjadi sampel adalah siswa kelas XII SMA Negeri 16 yang merupakan wakil dari populasi dengan cara cluster sampling.

Adapun instrumen yang digunakan adalah: (1) Lembar Penilaian yang dikembangkan oleh Peneliti untuk mendapatkan informasi tentang Modul Bimbingan Karier yang digunakan oleh Peneliti sudah memadai atau belum oleh pengguna dalam hal ini adalah siswa SMA Negeri 16 Surabaya, (2) wawancara yang merupakan bagian dari angket yang dikembangkan oleh Peneliti untuk menanyakan berbagai macam temuan yang tidak ada di angket namun perlu ditanyakan oleh Peneliti sekaligus menyempurnakan informasi yang diperoleh dari angket, dan (3) Dokumentasi berdasarkan dokumen yang ada yang digunakan Peneliti untuk mendapatkan data yang lebih lengkap seputar aplikasi modul Bimbingan Karier di SMA Negeri 16 Surabaya.

Analisis data yang digunakan menggunakan analisis data kombinasi yakni analisis data kuantitatif (menggunakan persentase dan rata-rata), sedangkan analisis yang lain adalah teknik analisis data kualitatif untuk menginterpretasikan data-data deskriptif dari hasil validasi ahli, desain dan teman sejawat atau praktisi.. Hasil analisis data nantinya menjadi sumber informasi Peneliti dalam menentukan kesimpulan dari hasil penelitian yang dilakukan oleh Peneliti.

\section{HASIL DAN PEMBAHASAN}

Hasil penelitian ini akan diuraikan berikut ini. Tahap Pertama, Peneliti melakukan dua kajian, yang terdiri dari (a) Kajian dari berbagai literatur yang menyangkut tentang bimbingan karier dan bimbingan kelompok serta karakter kinerja, termasuk berdiskusi dengan dosen pembimbing, teman sejawat guru BK di SMA Negeri 16 Surabaya dan para siswa di SMA Negeri 16 Surabaya. (b) Kajian lapangan, merupakan kajian yang dilakukan peneliti berdasarkan hasil observasi di kelas, temuan selama melakukan bimbingan kelompok pada siswa di SMA Negeri 16 Surabaya. Dari hasil kajian literatur dan kajian lapangan maka diperoleh gambaran betapa pentingnya pendampingan bimbingan karier pada siswa dengan bimbingan kelompok yang berbasis karakter kinerja dalam hal ini fokus nilai disiplin. Artinya penting untuk memahami karier yang didasari nilai disiplin yang tinggi, karena hal itu jadi modal yang baik untuk mencapai hasil yang terbaik. Sebagai hasil akhir dari kedua kajian diperoleh modul yang mengarah pada bimbingan karier dengan bimbingan kelompok berbasis karakter kinerja (nilai disiplin) dan didukung dengan media power point yang relevan nantinya untuk siswa SMA Negeri 16 Surabaya.

Tahap Kedua, peneliti melakukan rancangan penilaian instrumen, dengan cara menyusun instrumen, yang diawali dengan mendalami judul, kemudian variabel yang ditetapkan, dilanjutkan dengan sub variabel, dan dilanjutkan dengan deskriptor, indikator, serta butir-butir instrumen, atas dasar itulah butir-butir instrumen diperoleh yang sesuai dengan materi modul bimbingan karier dengan bimbingan kelompok berbasis karakter kinerja (fokus nilai disiplin) pada siswa SMA Negeri 16 Surabaya.

Tahap Ketiga, peneliti melakukan uji coba dari draf modul dan instrumen pada kelompok kecil sedang, dan besar, Dari uji coba kelompok kecil diperoleh hasil uji coba dan mendapatkan beberapa masukan terkait dengan modul, dan untuk kelompok sedang diuji cobakan dan mendapatkan beberapa masukan terkait dengan modul, dan untuk kelompok besar diuji cobakan sudah tidak ada revisi dari modul bimbingan karier berbasis karakter kinerja di SMA Negeri 16 Surabaya. Dari ketiga tahapan uji coba tersebut diharapkan mampu menghasilkan modul bimbingan karier berbasis karakter kinerja yang tepat. 
Dalam melakukan analisis kebutuhan, Peneliti melakukan kajian pada kondisi pengenalan dan pemahaman tentang BK di SMA Negeri 16 selama ini seperti apa., dan setelah diperoleh gambaran kondisi yang ada dapat masukan apa yang seharusnya dilakukan. Melakukan kajian BK yang ideal untuk SMA Negeri 16 Surabaya, dan pada mendapatkan pola atau gambaran yang tepat untuk SMA Negeri 16 Surabaya membutuhkan pola BK seperti apa. Kajian yang dilakukan oleh Peneliti merupakan tahapan analisis kebutuhan untuk memperoleh apa sebenarnya yang diharapkan di SMA Negeri 16 Surabaya terkait BK. Analisis Kebutuhan yang digunakan oleh Peneliti adalah Model Discrepancy (http://courses.phhp.ufl.edu/ rcs6740/ppt\%2006/need analysis.pdf.).

Untuk hasil uji desain dan isi modul, dilakukan oleh dua orang ahli dan satu orang praktisi. Hasilnya adalah sebagai berikut:

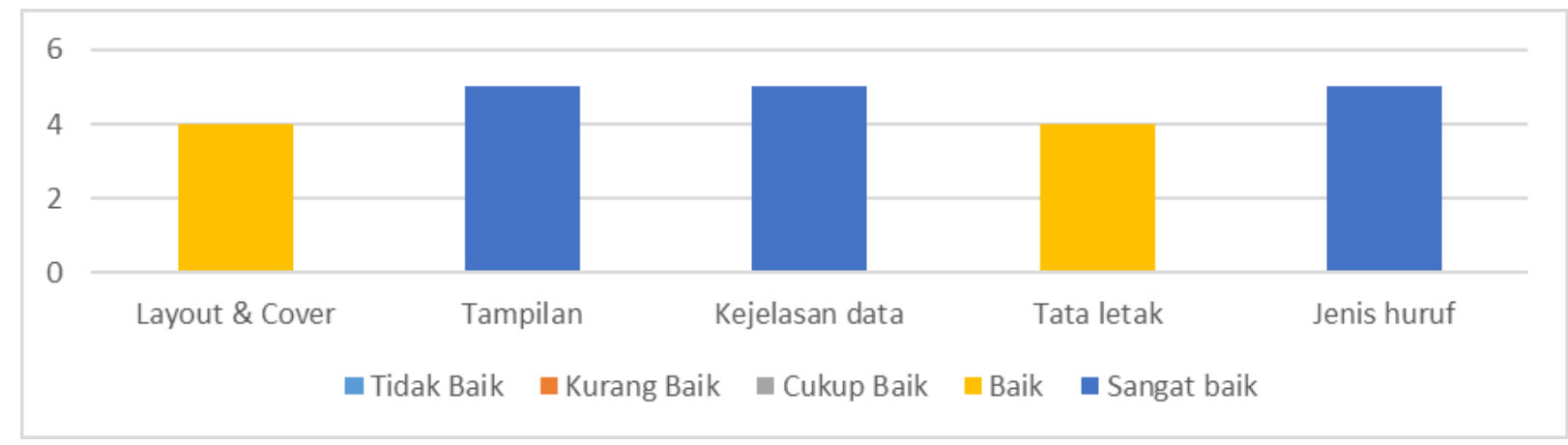

Grafik 1. Hasil Validasi Desain Modul

Sumber: Data diolah (Skala 1-5)

Dari grafik 1. Hasil validasi desain modul tersebut diperoleh nilai rata-rata 4.6 (baik) dengan persentase kevalidan sebesar $92 \%$.

Beberapa masukan secara tertulis dari validasi desain adalah perlu adanya perbaikan khususnya pada pin yang mendapatkan skor 4 atau baik untuk bisa lebih baik lagi, kedua poin itu adalah pada aspek (1) Lay out dan cover modul bimbingan karier, (2) Tata letak tulisan dan gambar dalam modul bimbingan karier. Atas saran masukan dari ahli desain tersebut maka perbaikan dilakukan pada poin 1 dan 2 , dengan melakukan revisi pada lay out dan cover dengan lebih menarik dan warna yang lebih cerah. Untuk perubahan yang dilakukan pada tata letak tulisan dan gambar di setiap unit dibuat lebih besar dan tulisan lebih besar serta dibentuk dalam penjelasan berbasis visual yang lebih mudah dipahami oleh siswa dan tidak hanya sebatas deskripsi saja.

Dari hasil perubahan dan revisi yang sudah dilakukan dan mendapatkan persetujuan dari pembimbing dan ahli desain untuk melanjutkan ke langkah selanjutnya. Setelah selesai diperbaiki dan dinyatakan layak maka sudah dapat menggunakan modul dalam kegiatan penelitian tahap berikutnya yakni pada tahap uji rancangan produk yakni uji coba produk kelompok, kelompok sedang dan kelompok besar.

Dari hasil perubahan dan revisi yang sudah dilakukan dan mendapatkan persetujuan dari pembimbing dan ahli desain untuk melanjutkan ke langkah selanjutnya. Setelah selesai diperbaiki dan dinyatakan layak maka sudah dapat menggunakan modul dalam kegiatan penelitian tahap berikutnya yakni pada tahap uji rancangan produk yakni uji coba produk kelompok, kelompok sedang dan kelompok besar.

Setelah dilakukan validasi desain maka dilanjutkan dengan melakukan validasi pada isi atau terkait dengan materi. Isi modul yang dikembangkan oleh Peneliti terangkum dalam Tabel 1. Struktur Modul sebagai berikut: 
Tabel 1. Struktur Modul

\begin{tabular}{ll}
\hline Unit & Isi \\
\hline 1 & Membahas tentang bimbingan karier diawali dengan membahas hasil yang \\
diharapkan dari unit 1, selanjutnya membahas tentang (a) Bimbingan Karier, (b) Fase \\
Bimbingan Karier, (c) Tujuan Bimbingan Karier, (d) Pertanyaan seputar Bimbingan \\
Karier yang merupakan bagian akhir dari Unit Satu ini. \\
Membahas tentang hasil yang diharapkan dari unit 2, kemudian dilanjutkan dengan \\
membahas Karier dan Jenis-jenis karier, pada unit dua ini beberapa hal yang \\
dipaparkan adalah (a) apa itu karier, (b) Jenis-Jenis Karier, (c) Pohon Karier, (d) \\
Pertanyaan Seputar Karier yang merupakan bagian akhir dari Unit Dua ini. \\
Membahas tentang hasil yang diharapkan dari unit 3, yang diteruskan dengan \\
memaparkan tentang Pemotivasian, pada unit tiga ini beberapa hal yang menjadi \\
pembahasan adalah (a) Motivasi Intrinsik dan Ekstrinsik, (b) Contoh-contoh motivasi \\
yang mendukung Karier, (c) Memberikan kata-kata motivasi terkait dengan Karier, \\
(d) Pertanyaan Seputar Pemotivasian yang merupakan bagian akhir dari Unit Tiga ini. \\
Membahas tentang hasil yang diharapkan dari unit 4, yang diteruskan dengan kajian \\
tentang Karakter Kinerja yang meliputi (a) Karakter, (b) Nilai Karakter Fokus Nilai \\
Disiplin, (c) Sifat Karakter Fokus Karakter Kinerja Nilai Disiplin, (d) Pertanyaan yang \\
mengarah pada Karakter Kinerja nilai disiplin yang merupakan bagian akhir dari Unit \\
ini.
\end{tabular}

Berdasarkan hasil validasi isi modul, maka terdapat dua aspek yang dinilai, antara lain dari sisi materi/isi, dan yang berikutnya kebahasaan. Berdasarkan faktor materi/isi, maka terdapat lima faktor yang diuji, yaitu (a) Esensialitas materi; (b) Kebenaran isi; (c) Kesesuaian isi; (d) Kesesuaian materi dengan model bimbingan; (e) Kesesuaian Tugas atau Pertanyaan dengan Isi/Materi. Hasil uji mendapati skor untuk keseluruhan aspek materi berada pada rentang angka empat dan lima.. ini menunjukkan hasil yang sangat baik terkait validasi isi modul.

Berikutnya adalah aspek kebahasaan yang terdiri dari lima aspek, yaitu: a Kebenaran
Tata Bahasa; b. Kesesuaian Kalimat dengan Kemampuan guru dan siswa; c. Kejelasan Petunjuk dan Arahan; d.Keefektifan Kalimat; e. Ejaan yang digunakan. Hasil penelitian juga mendapati bahwa faktor Bahasa dalam penyusunan modul tersebut mayoritas berada pada tingkatan yang sangat baik, dan hanya aspek kejelasan petunjuk yang memiliki nilai 4.

Berdasarkan hasil validasi isi modul di atas, maka faktor materi dan kebahasaan telah memenuhi kriteria yang disyaratkan. Berikutnya adalah validasi instrumen penilaian modul. Adapun hasil validasi tersebut terdapat di grafik 2. Hasil validasi instrumen modul sebagai berikut:

\begin{tabular}{|cl|} 
Rumusan pertanyaan & $\bullet$ Cukup jelas \\
\hline Cakupan dimensi & $\bullet$ Cukup lengkap \\
\hline Kenjabaran Variabel ke indikator & $\bullet$ Cukup lengkap \\
\hline Kesesuaian substansi dengan instrumen & $\bullet$ •sudah sesuai \\
\hline
\end{tabular}

Gambar 1. Hasil Validasi Instrumen Penilaian Modul

Sumber: Data diolah (Rentang jawaban 1-5) 
Untuk instrumen Peneliti melakukan kajian dari Judul, menjadi sub judul, kemudian sub komponen, dan dilanjutkan menjadi deskriptor,

dari deskriptor dilanjutkan menjadi indikator. Indikator-indikator tersebut yang menjadi dasar pernyataan yang dilengkapi dengan skala penilaian dengan rentang nilai 1-5 yang sudah ada di penjelasan sebelumnya. Setelah selesai divalidasi dan dinyatakan memenuhi maka diperoleh ada 8 indikator pertanyaan yang menjadi acuan dalam penilaian modul pada saat uji kelompok kecil, sedang dan besar. Meskipun demikian dalam proses pengembangan perbaikan kalimat yang tepat pada indikator masih dilakukan sehingga dapat menulis sesuai dengan maksud yang diharapkan oleh Peneliti.

Langkah berikutnya adalah menguji modul berdasarkan respons dari rekan sejawat. Untuk uji modul BK berbasis karakter kinerja dengan fokus pada nilai disiplin siswa pada teman sejawat dilakukan pada salah satu guru senior yang ada di SMA Negeri 16 Surabaya. Hasilnya adalah pada grafik 3 Hasil Penilaian Teman Sejawat berikut:

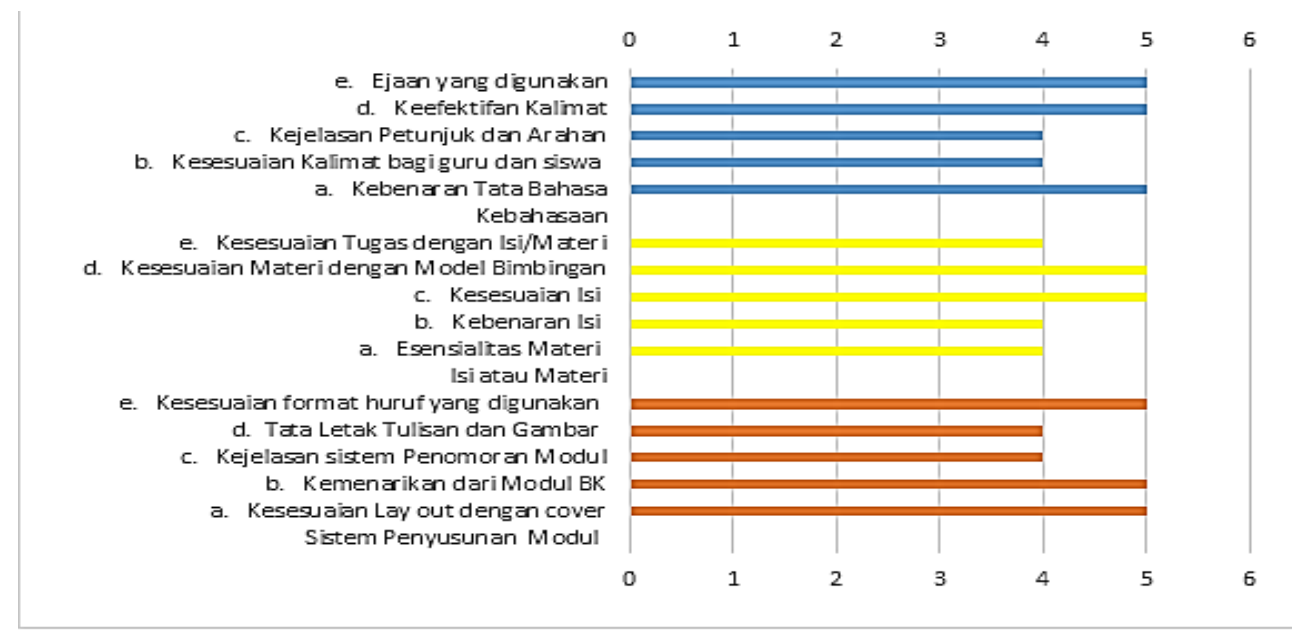

Grafik 2. Hasil Penilaian Teman Sejawat

Sumber: Data diolah (Rentang Jawaban 1-5)

Dari hasil penilaian teman sejawat maka diperoleh masukan untuk penjabaran yang lebih detail terkait dengan cara memberikan motivasi dan cara menguatkan nilai disiplin dalam modul selama proses bimbingan berlangsung di uji coba kelompok kecil maupun sedang dan besar. Hasil penilaian tersebut berada pada rentang 4 dan 5 yang menunjukkan baiknya modul yang digunakan.

Berikutnya adalah uji coba pada kelompok ajar kecil. Adapun hasil uji coba kelompok kecil dapat dijabarkan di grafik 4. Hasil Uji coba kelompok kecil sebagai berikut:

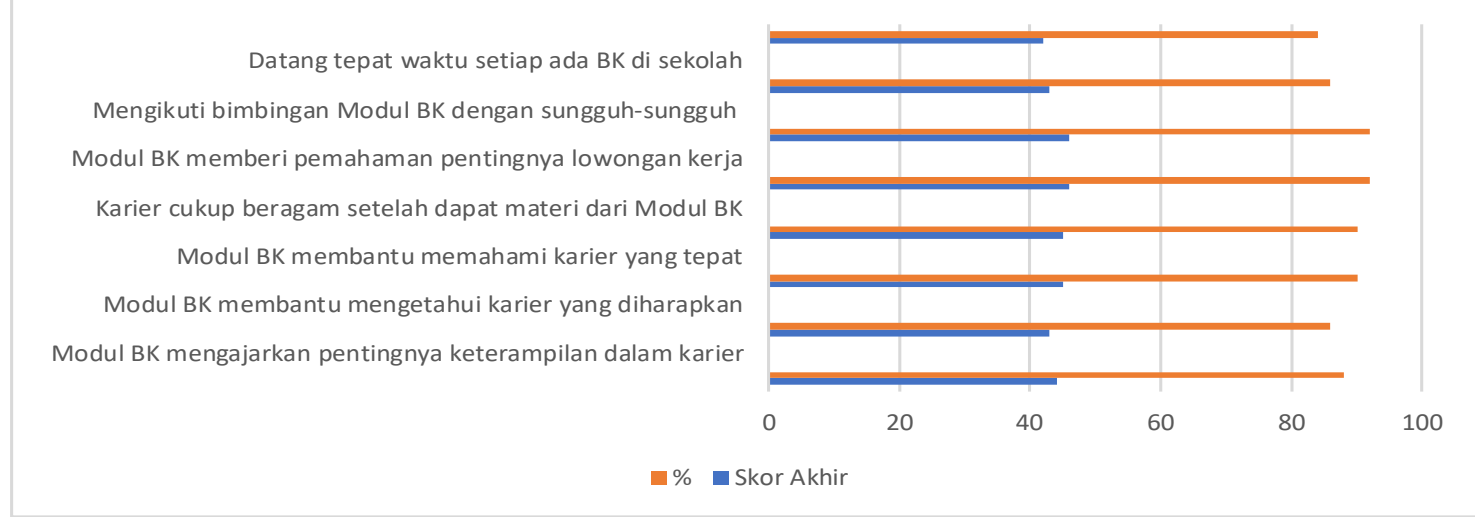

Grafik 3. Hasil uji coba kelompok kecil

Sumber: Data diolah, ( \% = Rerata Jawaban; Skor akhir = Total Jawaban Responden) 
Setelah mendapatkan hasil yang baik pada kelompok kecil, maka berikutnya dilakukan uji coba pada kelompok Hasil uji coba kelompok

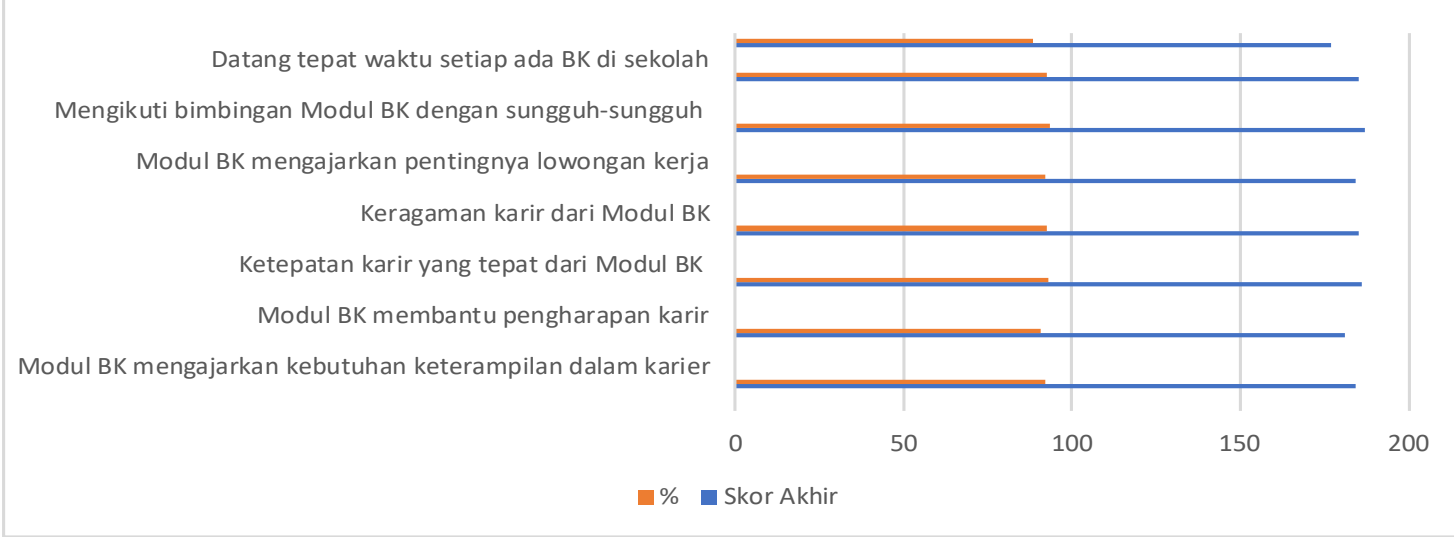

Grafik 4. Hasil uji coba kelompok sedang

Sumber: Data diolah, ( $\%$ = Rerata Jawaban; Skor akhir = Total Jawaban Responden)

Dari data yang sudah diperoleh maka dapat digambarkan hasil uji coba kelompok kecil berada pada $88.5 \%$ sehingga masih memerlukan perbaikan dalam beberapa hal sesuai dengan masukan dari hasil uji coba kelompok kecil di lapangan. Beberapa masukan yang diperoleh meliputi cara pemotivasian, dan cara penerapan nilai disiplin perlu dibuat lebih sederhana. Pemaparan lebih diperluas, petunjuk penggunaan dan prosedur penggunaan modul diperjelas agar sedang dapat dijabarkan di grafik 5. Hasil Uji coba Kelompok Sedang sebagai berikut: siswa bisa menggunakan modul dengan baik.

Untuk melanjutkan uji coba lapangan pada kelompok sedang Peneliti harus menyelesaikan uji coba kelompok kecil dan telah dilakukan beberapa revisi. Peneliti melakukan pengujian produk pada 5-15 Kelas sebanyak 30-100 subjek. Untuk uji coba kelompok sedang Modul BK SMA Negeri 16 Surabaya Berbasis Karakter Kinerja fokus nilai disiplin sebanyak 40 siswa Kelas XII.

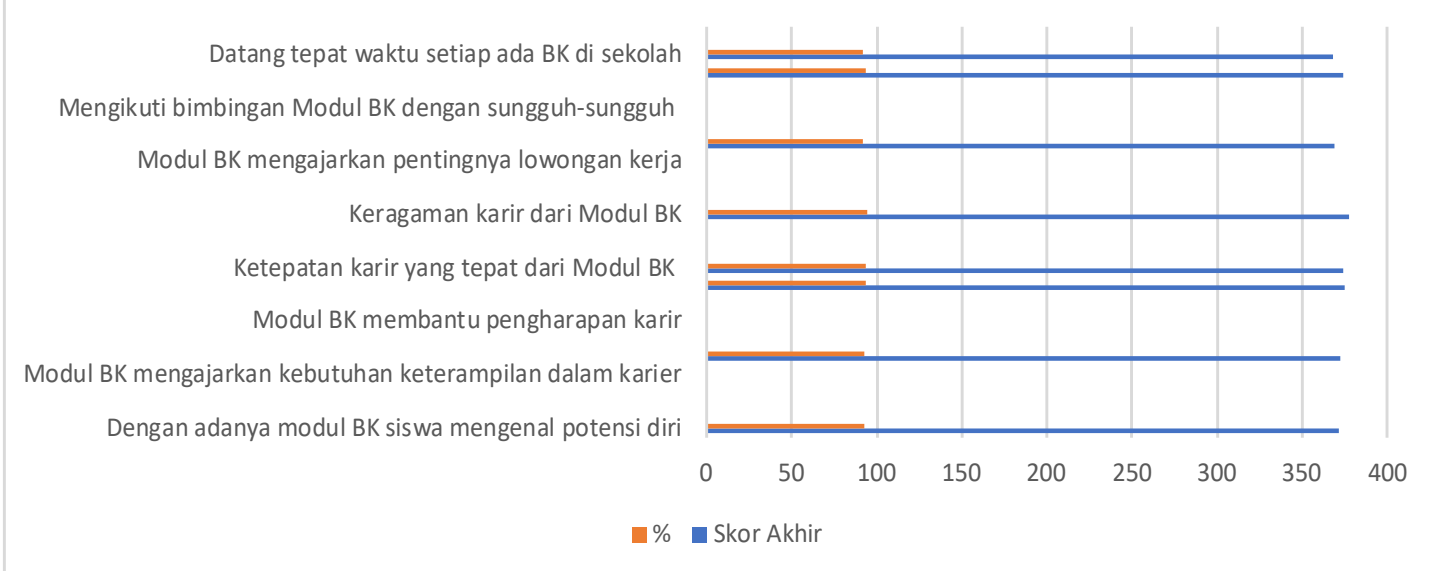

Grafik 5. Hasil uji coba kelompok besar

Sumber: Data diolah, (\% = Rerata Jawaban; Skor akhir = Total Jawaban Responden) 
Dari data yang sudah diperoleh dari hasil uji coba pada 40 siswa kelas XII sebagai subjek penelitian dan sudah dianalisis pada grafik 5 Hasil uji coba kelompok sedang maka dapat digambarkan hasil uji coba yang telah dilakukan pada kelompok sedang berada pada $91.8 \%$, dari perolehan persentase tersebut masih memerlukan perbaikan yang disampaikan oleh subjek penelitian sehingga masih ada masukan yang memerlukan perbaikan yang mengarah pada paparan petunjuk penggunaan modul masih perlu konsistensi.

Beberapa hal lain yang sudah dilakukan di uji coba kelompok kecil dan sudah diperbaiki masih ada beberapa masukan yang diperoleh meliputi contoh motivasi lainnya ditambah, dan cara penerapan nilai disiplin sudah dianggap baik oleh subjek penelitian. Pemaparan lebih banyak diberikan contoh dan diperluas juga sudah dilakukan di kelompok kecil sebagai bagian dari perbaikan sudah dinilai lebih baik.

Untuk melanjutkan uji coba lapangan pada kelompok yang terakhir yakni uji coba kelompok besar Peneliti sudah harus menyelesaikan uji coba kelompok sedang dan telah dilakukan beberapa revisi sesuai dengan masukan atau temuan hasil uji lapangan.

Peneliti melakukan pengujian produk pada 10-30 Kelas, atau sebanyak 40-400 subjek. Untuk uji coba kelompok besar pada Modul BK SMA Negeri 16 Surabaya Berbasis Karakter Kinerja fokus nilai disiplin sebanyak 80 siswa Kelas XII.

Dari data yang sudah diperoleh dari hasil uji coba yang dilakukan pada kelompok besar sebanyak 40 subjek atau siswa kelas XII SMA Negeri 16 Surabaya sebagai subjek penelitian dan sudah dianalisis pada grafik 5 Hasil uji coba kelompok sedang dan 6. Hasil Uji coba kelompok besar digambarkan hasil uji coba yang telah dilakukan pada kelompok sedang berada pada $92.8 \%$, dari perolehan persentase tersebut masih ada sedikit perbaikan yang disampaikan oleh subjek penelitian sehingga masih ada masukan yang memerlukan perbaikan yang mengarah pada penerapan nilai disiplin beserta contoh terbaiknya.

Beberapa hal lain yang sudah dilakukan di uji coba kelompok kecil dan sudah diperbaiki masih ada beberapa masukan yang diperoleh meliputi contoh motivasi lainnya ditambah, dan cara penerapan nilai disiplin sudah dianggap baik oleh subjek penelitian. Pemaparan lebih banyak diberikan contoh dan diperluas juga sudah dilakukan di kelompok kecil sebagai bagian dari perbaikan sudah dinilai lebih baik.

Untuk uji coba kelompok besar pada Modul BK SMA Negeri 16 Surabaya Berbasis Karakter Kinerja fokus nilai disiplin sebanyak 80 siswa Kelas XII. Hasilnya terangkum dalam grafik 6 . Hasil uji coba kelompok besar berikut:

Berdasarkan hasil analisis pada uji kelompok kecil, uji kelompok sedang dan uji kelompok besar dapat diambil suatu ringkasan bahwa modul yang dikembangkan oleh Peneliti yakni Modul bimbingan karier Siswa SMA Negeri 16 Surabaya berbasis karakter kinerja yang fokus pada nilai disiplin sudah dinyatakan layak dengan tingkat kelayakan dari uji kelompok kecil rata-rata. 88,5. \%, uji kelompok sedang dengan persentase tingkat kelayakan rata-rata $91.8 \%$ dan untuk uji kelompok besar adalah 93.1\%.

Pada umumnya revisi dilakukan pada uji coba kelompok kecil dan kelompok sedang, dan tidak menutup kemungkinan pada uji kelompok besar bisa terjadi. Revisi dari uji kelompok kecil yang difokuskan pada nilai disiplin yang memang menjadi modal dasar dalam dunia kerja, seperti datang tepat waktu, menyelesaikan tugas sesuai dengan waktu yang sudah ditentukan, selain dari pengetahuan dan pengalaman yang dimilikinya. Revisi juga dilakukan pada petunjuk penggunaan modul sehingga apa yang sudah dirancang tidak hanya melakukan bimbingan karier namun dikuatkan sisi disiplinnya selama melakukan BK.

Beberapa keunggulan yang dimiliki oleh modul yang dikembangkan oleh Peneliti adalah sebagai berikut, (1) Modul bimbingan karier yang berbasis karakter kinerja di SMA Negeri 16 Surabaya menggunakan model yang dikembangkan Borg dan Gall yang berorientasi pada kebutuhan bimbingan konseling di tingkat SMA. (2) Modul bimbingan karier disusun berangkat dari kajian analisis kebutuhan dan perancangan yang sesuai dengan acuan pengembangan produk 
yang divalidasi oleh ahli desain, ahli isi dan dilengkapi instrumen pendukungnya, yang kemudian dilanjutkan pada uji coba lapangan dan sampai revisi produk yang pada akhirnya produk sudah siap digunakan. (3) Modul ini sudah dinyatakan layak dan memadai oleh para ahli baik secara desain, isi dan instrumen pendukungnya. (4) Adanya modul yang sudah dikembangkan oleh Peneliti dapat membantu guru BK dalam melakukan pendampingan Bimbingan Karier dan membantu siswa untuk lebih mudah memahami tentang karier. (5) Modul yang dikembangkan sudah melalui tahapan yang komprehensif baik kajian literatur, ahli dan praktisi. (6) Modul yang dikembangkan di desain sesuai dengan kebutuhan di lapangan baik secara penataan cover, isi serta urutan materi serta tata letak yang tepat untuk isian modul, termasuk tata tulis yang sesuai dengan penggunaan kebutuhan siswa selama bimbingan karier.

Beberapa kelemahan yang dimiliki oleh modul yang dikembangkan oleh adalah sebagai berikut. (1) Modul bimbingan karier dalam pelaksanaannya masih menggunakan kertas dan bantuan media lain seperti papan tulis white board, LCD yang membuat sistem kerja bimbingan karier kurang praktis; dan (2) Modul bimbingan karier yang dikembangkan masih dalam taraf penelitian sehingga memerlukan sosialisasi yang memadai di lingkungan SMA Negeri 16 Surabaya untuk kelas XII, dan modul ini hanya digunakan di SMA Negeri 16 Surabaya karena melibatkan siswa SMA Negeri 16 Surabaya.

Pada saat peneliti melakukan pengembangan modul BK di SMA Negeri 16 Surabaya ada beberapa kesulitan yang dihadapi, yakni: (1) Kajian bimbingan karier yang berbasis karakter kinerja khususnya nilai disiplin masih dihadapkan pada kajian materi modul yang lebih mendalam dan komprehensif; (2) Waktu yang tersedia cukup terbatas, mulai dari analisis kebutuhan, validasi ahli dan praktisi sampai pada uji coba produk kelompok kecil, sedang dan besar sampai pada produk akhir, maka pemanfaatan waktu menjadi penentu dalam penyelesaian modul BK di SMA Negeri 16 Surabaya; (3)Pengembangan modul BK yang dikembangkan oleh Peneliti untuk karakter kinerja hanya nilai disiplin saja tidak pada nilai- nilai yang lainnya. Peneliti berupaya untuk menyusun dan mengembangkan sendiri modul yang nantinya bisa digunakan di SMA Negeri 16 Surabaya, (4) Pengembangan modul BK di SMA Negeri 16 Surabaya sudah melalui proses yang cukup panjang yang pada akhirnya dapat dinilai ada perbaikan-perbaikan yang lebih baik sesuai kebutuhan sehingga dapat digunakan untuk siswa kelas XII.

\section{Pembahasan}

Konseling merupakan kegiatan profesional yang dilakukan oleh konselor untuk mempersiapkan potensi kerja di masa yang akan datang, beragam persiapannya, kesehatan mental, diskusi keluarga dan lainlain bagi para siswa (Bain, 2012). Karenanya, peran ini menjadi fungsi penting lain yang disediakan sekolah selain guru yang mengajarkan topik di kelas.

Penelitian ini membahas isu pengembangan bahan ajar dalam bentuk modul pembelajaran berbasis pendidikan karakter. Idealnya pengembangan modul membutuhkan tim kerja yang lengkap, atau tim desain mata kuliah (Handelzalts, 2019). Berbekal desain penelitian pengembangan, modul penelitian dikembangkan dengan menguji coba modul pada berbagai kelompok siswa. Tujuannya adalah untuk mendapatkan masukan yang komprehensif dan sesuai dengan kebutuhan pembelajaran. Peran siswa amat penting bagi dan menjadi keunggulan tersendiri dengan munculnya pola pikir kritis siswa (Barbay, Simmonds, Nishida, \& Ribeiro, 2016). Peran kepemimpinan guru yang mau aktif dalam pengembangan modul perkuliahan ini menjadi salah satu penentu utama keberhasilan pencapaian target ajar (Lai \& Cheung, 2015).

Hasil penelitian ini sesuai dengan hasil penelitian bahwa penggunaan modul bimbingan dapat meningkatkan kualitas layanan bimbingan dan konseling dengan penguasaan dan pengembangan media layanan (Leksana, 2015). Pemetaan keahlian siswa akan sangat berguna untuk menyusun potensi lowongan kerja yang sesuai (Septani et al., 2019).

Hasil penelitian menunjukkan penggunaan modul memiliki pengaruh positif terhadap 
peningkatan pemahaman guru BK dalam menyusun program BK komprehensif di sekolah (Hanggara, 2016). Hasil ini sejalan dengan studi Na'imah dan Rahardjo yang mendapati hasil positif dari pengembangan modul pembelajaran perencanaan karier, walaupun ini membuat siswa siap untuk menjadi pekerja dan bukannya pengusaha (Na'imah \& Rahardjo, 2012). Padahal menjadi wirausahawan merupakan salah satu kriteria penting di era globalisasi saat ini (Amar, Syariati, \& Rahim, 2019). Ini menjadi salah satu kritik terhadap bentuk pengajaran kepada siswa untuk siap bekerja, dan bukannya menciptakan lapangan pekerjaan. Beberapa penelitian telah mengkritisi luaran sekolah vokasi yang fokus pada pekerjaan, dan membuat mantan siswa sulit beradaptasi ketika telah mencapai usia tertentu (Forster et al., 2016; Hampf \& Woessmann, 2017; Hanushek et al., 2017).

Peneliti lainnya mendapati bahwa pengembangan modul ajar yang baru idealnya menyandingkan dua metode yang berbeda, untuk mendapatkan hasil yang lebih komprehensif (Asunka, 2015). Penguatan kecerdasan spiritual dan emosional juga mampu memberi sumbangsih penting bagi pengembangan kemampuan siswa didik (Parmitasari, Alwi, \& S., 2018; Suhartini \& Anisa, 2017).

Modul ajar haruslah terus-menerus berkembang. Fakta bahwa banyak modul ajar yang berasal dari penelitian pengembangan yang sudah tua, bisa menghambat daya adaptasi siswa terhadap perubahan zaman yagn semakin cepat (Galassi \& Akos, 2007:4); karenanya, penelitian pengembangan modul ajar konseling menjadi salah satu jawaban, karena kemampuannya untuk mendapatkan solusi skala kecil dan mendalam (Lijnse, 1995). Penggunaan penelitian pengembangan telah terbukti mampu memberikan dampak positif pada aktivitas pengajaran (Nawawi, Degeng, \& Cholid, 2019; D. Riyadi, Degeng, \& Junining, 2019). Tentunya dengan menciptakan modul yang kaya akan aktivitas, dan bukannya teori semata (Choo, 2007). Hasil penelitian ini memberikan keyakinan atas penggunaan modul ajar bimbingan karier yang diharapkan.

\section{SIMPULAN}

Dari kajian yang sudah dijelaskan sebelumnya maka dapat diambil suatu simpulan sebagai bahwa Pengembangan Modul Bimbingan Karier berbasis Karakter Kinerja di SMA Negeri 16 Surabaya dapat dilaksanakan dan diaplikasikan pada siswa kelas XII. Berikutnya, pengembangan Modul Bimbingan Karier berbasis Karakter Kinerja di SMA Negeri 16 Surabaya dinyatakan layak untuk digunakan di SMA Negeri 16 Surabaya kelas XII; dan pendampingan bimbingan karier dengan menggunakan Modul Bimbingan Karier berbasis Karakter Kinerja tidak hanya membantu siswa memahami tentang karier dan memilih karier namun juga memiliki bekal karakter kinerja dan nilai disiplin yang memadai. Hasil penelitian juga mendapati Pendampingan bimbingan karier dengan adanya Modul Bimbingan Karier berbasis karakter Kinerja mendukung siswa belajar lebih mandiri dan disiplin.

\section{DAFTAR PUSTAKA}

Abel, J. R., Deitz, R., \& Su, Y. (2014). Are recent college graduates finding good jobs? Current Issues in Economics and Finance.

Amar, M. Y., Syariati, A., \& Rahim, F. R. (2019). Enhancing hotel industry performance through service based resources and strategic enterpreneurship (Case Study At Hotel Industries In Indonesia). Academy of Entrepreneurship Journal, 25(3), 1-10.

Asunka, S. (2015). Blend or Flip: an Assessment of Graduate Students' Preferences for Technology-Enabled Learning Initiatives Within the SubSaharan African Context. In Inted2015: 9th International Technology, Education and Development Conference.

Bain, S. F. (2012). School counselors: a review of contemporary issues. In Research in Higher Education Journal .

Barbay, J., Simmonds, J., Nishida, A. K., \& Ribeiro, M. P. (2016). "Teaching is learning": Pedagogical material created and evaluated by students. Proceedings - Frontiers in Education Conference, FIE.https://doi.org/10.1109/ FIE.2016.7757598 
Choo, C. B. (2007). Activity-based Approach to Authentic Learning in a Vocational Institute. Educational Media International. https://doi. org/10.1080/09523980701491633

Falco, L. D. (2017). The School Counselor and STEM Career Development. Journal of Career Development. https://doi. org/10.1177/0894845316656445

Forster, A. G., Bol, T., \& van de Werfhorst, H. G. (2016). Vocational education and employment over the life cycle. Sociological Science. https://doi. org/10.15195/v3.a21

Galassi, J. P., \& Akos, P. (2007). Strengthsbased school counseling: Promoting student development and achievement. In Strengths-based school counseling: Promoting student development and achievement.

Gall, M. D., Gall, J. P., \& Borg, W. R. (2003). Educational research: An introduction (7th ed.). In Boston, MA: $A \& B$ Publications.

Hampf, F., \& Woessmann, L. (2017). Vocational vs. general education and employment over the life cycle: New evidence from PIAAC. CESifo Economic Studies. https:// doi.org/10.1093/cesifo/ifx012

Handelzalts, A. (2019). Collaborative Curriculum Development in Teacher Design Teams. In Collaborative Curriculum Design for Sustainable Innovation and Teacher Learning. https://doi.org/10.1007/978-3030-20062-6_9

Hanggara, G. (2016). Keefektifan "Proses Guru" sebagai Teknik Bimbingan Kelompok dalam Meningkatkan Pengambilan Keputusan Karier Siswa SMK. Jurnal Kajian Bimbingan Dan Konseling. https://doi.org/10.17977/ um001v1i42016p148

Hanushek, E. A., Schwerdt, G., Woessmann, L., \& Zhang, L. (2017). General education, vocational education, and labor-market outcomes over the lifecycle. Journal of Human Resources. https://doi. org/10.3368/jhr.52.1.0415-7074R

Lai, E., \& Cheung, D. (2015). Enacting teacher leadership:The role of teachers in bringing about change. Educational

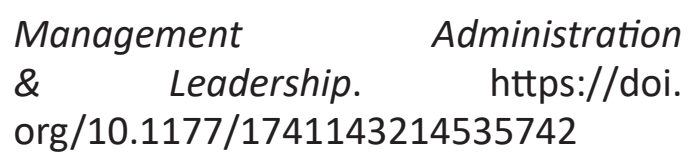

Leksana, D. M. (2015). Pengembangan Modul Bimbingan Karier Berbasis Multimedia Interaktif Untuk Meningkatkan Kematangan Karier Siswa. AKADEMIKA. https://doi.org/10.30736/akademika. v9i2.69

Lijnse, P. L. (1995). "Developmental research" as a way to an empirically based "didactical structure" of science. Science Education. https://doi.org/10.1002/ sce.3730790205

Morgan, L. W., Greenwaldt, M. E., \& Gosselin, K. P. (2014). School Counselors' Perceptions of Competency in Career Counseling. The Professional Counselor. https://doi.org/10.15241//wm.4.5.481

Na'imah, T., \& Rahardjo, P. (2012). Development Of Career Guidance Modul For Increasing Youth Enterpreneurship. Proyeksi. https://doi. org/10.30659/p.7.1.55-66

Nawawi, N., Degeng, N., \& Cholid, A. (2019). Development of Video Media To Increase Dribbling Learning Result In A Sport GAMES. Edcomtech Jurnal Kajian Teknologi Pendidikan. https://doi. org/10.17977/um039v4i22019p083

Parmitasari, R. D. A., Alwi, Z., \& S., S. (2018). Pengaruh Kecerdasan Spritual dan Gaya Hidup Hedonisme terhadap Manajemen Keuangan Pribadi Mahasiswa Perguruan Tinggi Negeri di Kota Makassar. Jurnal Minds: Manajemen Ide Dan Inspirasi. https://doi.org/10.24252/minds. v5i2.5699

Riyadi, D., Degeng, P., \& Junining, E. (2019). Developing Instructional Game "Adventure Of Word" To Improve Morphological Awareness On Vocational Higher Students. Edcomtech Jurnal Kajian Teknologi Pendidikan. https:// doi.org/10.17977/um039v4i22019p153 Riyadi, D. K., Dian, P., Degeng, D., \& Junining, E. (2019). Edcomtech. Developing Instructional Game "Adventure Of Word" to Improve Morphological Awareness on Vocational Higher Students, 4,(2,), 153-162. 
Septani, N., Elmunsya, H., \& Pujianto, U. (2019). Rekomendasi Pemetaan Keahlian Siswa Terhadap Spesifikasi Lowongan Kerja Pada Sistem Bursa Kerja Khusus (Bkk) Menggunakan Metode Simple Additive Weighting (Saw) Di Smk. Edcomtech Jurnal Kajian Teknologi Pendidikan. https://doi.org/10.17977/ um039v4i22019p120

Sugiyono, P. D. metode penelitian kuantitatif, kualitatif,dan R\&D. , Alfabeta, cv. (2016).
Suhartini, E., \& Anisa, N. (2017). Pengaruh Kecerdasan Emosional Dan Kecerdasan Spiritual Terhadap Kinerja Perawat Rumah Sakit Daerah Labuang Baji Makassar. Jurnal Minds: Manajemen Ide Dan Inspirasi. https://doi.org/10.24252/ minds.v4i1.3135 